\title{
Evaluation of the immune response induced by a mite derived fusion protein in BALB/c mice
}

\author{
Dalgys Martinez ${ }^{1 *}$, Leonardo Puerta ${ }^{1,2}$, Ines Benedetti $^{3}$, Marlon Munera ${ }^{1}$, Luis Caraballo ${ }^{1,2}$ \\ From 3rd WAO International Scientific Conference (WISC) 2014 \\ Rio de Janeiro, Brazil. 6-9 December 2014
}

\section{Background}

The mite Dermatophagoides pteronyssinus is an important source of allergens and a major risk factor for allergic rhinitis and asthma. A more effective and safe way for allergen specific immunotherapy could be using recombinant allergens or their derivatives, such as hybrid molecules. This study was aimed to evaluate the immune response induced in mice by a hybrid recombinant protein, harboring several segments of major allergens of $D$. pteronyssinus.

\section{Methods}

We engineered a fusion protein called DPx4 assembling segments of four allergens of $D$. pteronyssinus in a single molecule. Three 8 female BALB/c mice groups were immunized on days $0,7,14$ and 21 as follows: group 1 with 10 ug of DPx4, group 2 with 20 ug D. pteronyssi$n u s$ extract and group 3 with PBS, antigens and PBS were adsorbed to $\mathrm{Al}(\mathrm{OH})_{3}$. After immunization each animal was challenged four times intranasally. Total IgE, IgG2a and IgG1 levels were determined by ELISA. Bronchial hyperreactivity was evaluated by methacholine challenge and measurement of means enhanced pause (Penh). Mucus production in lung was evaluated with periodic acid-Schiff (PAS) and cellular infiltrate by hematoxylin-eosin staining.

\section{Results}

Animals treated with DPx4 showed significantly lower total IgE and IgG 1 levels compared with mice treated with extract, while the IgG2a levels were higher but not statistically significant. Administration of DPx4 induced lower, but not statistically significant, bronchial hyperreactivity than that induced by administration of D. pteronyssinus. Treatment with DPx4 induced significantly lower inflammation around the peribronchial and

${ }^{1}$ Institute for Immunological Research, University of Cartagena, Colombia Full list of author information is available at the end of the article perivascular zones than treatment with extract. The PAS staining revealed goblet cell hyperplasia and mucus hypersecretion in the bronchi of mice treated with $D$. pteronyssinus extract but not in mice treated with DPx4.

\section{Conclusions}

The administration of DPx4 in a mice model of asthma induced a less bronchial inflammatory immune response than the mite extract, suggesting that it has potential value for the development of a mite allergen vaccine. Funded by Colciencias Grant No. 385-2009.

\section{Authors' details}

${ }^{1}$ Institute for Immunological Research, University of Cartagena, Colombia. ${ }^{2}$ Foundation for the Development of Medical and Biological Sciences, Colombia. ${ }^{3}$ University of Cartagena, School of Medicine, Colombia.

Published: 8 April 2015

doi:10.1186/1939-4551-8-S1-A18

Cite this article as: Martinez et al: Evaluation of the immune response induced by a mite derived fusion protein in BALB/c mice. World Allergy Organization Journal 2015 8(Suppl 1):A18.

Submit your next manuscript to BioMed Central and take full advantage of:

- Convenient online submission

- Thorough peer review

- No space constraints or color figure charges

- Immediate publication on acceptance

- Inclusion in PubMed, CAS, Scopus and Google Scholar

- Research which is freely available for redistribution 